\title{
Canadian pediatric gastroenterology workforce: Current status, concerns and future projections
}

\author{
Véronique Morinville MDCM FRCPC ${ }^{1,3}$, Éric Drouin MD FRCPC ${ }^{1,3}$, Dominique Lévesque MD FRCPC ${ }^{1,4}$, \\ Victor M Espinosa MSC ${ }^{5}$, Kevan Jacobson MD FRCPC $1,2,6$
}

\begin{abstract}
V Morinville, É Drouin, D Lévesque, VM Espinosa, K Jacobson. Canadian pediatric gastroenterology workforce: Current status, concerns and future projections. Can J Gastroenterol 2007;21(10):653-664.
\end{abstract}

BACKGROUND: There is concern that the Canadian pediatric gastroenterology workforce is inadequate to meet health care demands of the pediatric population. The Canadian Association of Gastroenterology Pediatric Committee performed a survey to determine characteristics and future plans of the Canadian pediatric gastroenterology workforce and trainees.

METHODS: Estimates of total and pediatric populations were obtained from the 2001 Census of Population, Statistics Canada (with estimates to July 1, 2005). Data on Canadian pediatric gastroenterologists, including clinical full-time equivalents, sex, work interests, opinions on workforce adequacy, retirement plans, fellowship training programs and future employment plans of fellows, were gathered through e-mail surveys and telephone correspondence in 2005 and 2006.

RESULTS: Canada had an estimated population of 32,270,507 in $2005(6,967,853$ people aged zero to 17 years). The pediatric gastroenterology workforce was estimated at 9.2 specialists per million children. Women accounted for $50 \%$ of the workforce. Physician to pediatric population ratios varied, with Alberta demonstrating the highest and Saskatchewan the lowest ratios (1:69,404 versus 1:240,950, respectively). Between 1998 and 2005, Canadian pediatric gastroenterology fellowship programs trained 65 fellows (65\% international trainees). Twenty-two fellows (34\%) entered the Canadian workforce.

CONCLUSIONS: The survey highlights the variable and overall low numbers of pediatric gastroenterologists across Canada, an increasingly female workforce, a greater percentage of part-time physicians and a small cohort of Canadian trainees. In conjunction with high projected retirement rates, greater demands on the workforce and desires to partake in nonclinical activities, there is concern for an increasing shortage of pediatric gastroenterologists in Canada in future years.

\section{Effectifs en gastroentérologie pédiatrique au Canada : Situation actuelle, craintes et projections}

\begin{abstract}
HISTORIQUE : On s'inquiète du fait que les effectifs en gastroentérologie pédiatrique au Canada sont insuffisants pour répondre à la demande en matière de soins de santé dans la population pédiatrique. Le comité de pédiatrie de l'Association canadienne de gastroentérologie a procédé à une enquête afin de d'identifier les caractéristiques et les plans futurs des effectifs et des résidents en gastroentérologie pédiatrique au Canada.

MÉTHODES : Les estimations des populations totale et pédiatrique ont été tirées du recensement de Statistique Canada pour 2001 (avec estimations jusqu'au $1^{\text {er }}$ juillet 2005). Les données sur les gastroentérologues pédiatriques canadiens, y compris les équivalents de temps complet cliniques, le sexe, les intérêts professionnels, les opinions sur l'équilibre des effectifs, les plans de retraite, les programmes de spécialisation et les plans de carrière des fellows ont été recueillies par voie d'enquêtes réalisées par courriel et par téléphone en 2005 et en 2006.
\end{abstract}

RÉSULTATS : La population du Canada était estimée à 32270507 habitants pour 2005 (dont 6967853 âgés de 0 à 17 ans). Les effectifs en gastroentérologie pédiatrique ont pour leur part été évalués à 9,2 spécialistes par million d'enfants, les femmes représentant $50 \%$ de ces effectifs. Les rapports médecin:population pédiatrique variaient, l'Alberta ayant obtenu le rapport le plus élevé et la Saskatchewan, le plus bas (1:69 404, contre 1:240 959, respectivement). Entre 1998 et 2005, les programmes de résidence en gastroentérologie pédiatrique au Canada ont formé $65 \mathrm{fel}$ lows (65\% d'autres origines) et 22 d'entre eux (34\%) ont choisi de faire carrière au Canada.

CONCLUSION : Cette enquête a mis en lumière les faits suivants : le nombre variable et généralement faible des gastroentérologues pédiatriques au Canada, des effectifs de plus en plus composés de femmes, un pourcentage plus élevé de médecins à temps partiel et une faible cohorte de résidents d'origine canadienne. En conjonction avec les taux élevé de mise à la retraite projetés, l'augmentation de la demande et le désir de participer à des activités non cliniques, il y a lieu de s'inquiéter de la pénurie croissante de gastroentérologues pédiatriques au Canada pour les années à venir.

Key Words: Canada; Gastroenterology; Manpower; Pediatrics

There is increasing concern over the presence and availability of various medical specialists across North America, including pediatric gastroenterologists. The recent North American Society for Pediatric Gastroenterology, Hepatology and Nutrition (NASPGHAN) pediatric gastroenterology workforce survey, which included Canadian data, highlighted this concern (1). In the NASPGHAN survey, compared with a similar survey completed in 1996 (2), a higher percentage of

${ }^{1}$ Canadian Association of Gastroenterology Pediatric Gastroenterology Committee, 2005; 2Past Chairman, Canadian Association of

Gastroenterology Pediatric Gastroenterology Committee; ${ }^{3}$ Division of Pediatric Gastroenterology and Nutrition, Montreal Children's Hospital,

McGill University Health Centre; ${ }^{4}$ Division of Pediatric Gastroenterology and Nutrition, Hôpital Ste-Justine, Université de Montréal,

Montreal, Quebec; ${ }^{5}$ Child and Family Research Institute; ${ }^{6}$ Division of Pediatric Gastroenterology, British Columbia Children's Hospital and

Child and Family Research Institute, University of British Columbia, Vancouver, British Columbia

Correspondence and reprints: Dr Kevan Jacobson, British Columbia's Research Institute and British Columbia's Children's Hospital, Division of Gastroenterology, 4480 Oak Street, Room K4-181, Vancouver, British Columbia, V6H 3V4. Telephone 604-875-2332, fax 604-875-3244, e-mail kjacobson@cw.bc.ca

Received for publication December 31, 2006. Accepted January 18, 2007 
respondents indicated inadequate numbers of practicing pediatric gastroenterologists in their area $(53 \%$ and $76 \%$ of American and Canadian current respondents, respectively, versus $12 \%$ and $57 \%$ of American and Canadian respondents, respectively, in the previous survey). A concerning trend across North America, as demonstrated in the more recent workforce survey (1), is the high proportion of current pediatric gastroenterologists who plan to retire in the next decade. Moreover, $50 \%$ of section and practice heads reported that they were currently recruiting members to their divisions, suggesting a need for additional pediatric gastroenterologists (1). While data are lacking in Canada, it has been the perception of the gastroenterology community that the numbers of practicing pediatric gastroenterologists are insufficient to support the current needs of the Canadian health care system. Furthermore, there is concern that the numbers of current trainees are inadequate to fulfill the current needs, with the shortage further intensified by ongoing pediatric gastroenterologist retirements.

The Pediatric Committee of the Canadian Association of Gastroenterology (CAG) undertook a study to determine the current status of pediatric gastroenterologists and clinical nutritionists in Canada, and to examine future manpower issues with respect to currently practicing physicians, retirement plans and current trainees.

\section{METHODS}

The following Canadian pediatric manpower issues were reviewed:

- status of the Canadian population (overall, by province and by pediatric populations);

- status of the pediatric gastroenterology workforce;

- full-time equivalents (FTEs) and clinical FTEs;

- ratio of the pediatric population (overall, by province and by centre) to pediatric gastroenterologists;

- sex distribution;

- age of the workforce, retirement plans, primary area of interest, opinions on workforce adequacy and recruitment;

- status of pediatric gastroenterology trainees (past and present);

- status of the pediatric gastroenterology fellowship training programs; and

- projected estimates of the future Canadian pediatric gastroenterology workforce.

\section{Canadian population and distribution (2001 to 2005)}

The estimates of the Canadian population and provincial distributions were obtained from the 2001 Census of Population, Statistics Canada (3). The data gathered included the overall population, as well as available information on the pediatricaged population. Total Canadian and provincial population estimates and pediatric population estimates for people aged zero to 17 years, zero to 18 years, and zero to 19 years were adapted from Statistics Canada, 2001 Census data, and Statistics Canada community profiles, catalogue number 97F0003XCB2001001, Provincial Census 2001. Estimates of the total Canadian population, pediatric population and provincial distributions, as of July 1, 2005 (determined during 2004), were adapted and generated from CANSIM Table 051-0001 (3).

Canadian pediatric gastroenterology workforce (2005/2006) A list of pediatric gastroenterologists, with their sex and e-mail addresses, was compiled using the NASPGHAN and CAG membership databases. A pediatric gastroenterologist was defined as a physician currently providing pediatric gastroenterological, hepatological care and/or nutritional care, or a physician involved in teaching, administration or research related to pediatric gastroenterology, hepatology and nutrition. An additional definition was provided for clinical nutritionists involved in nutritional support of pediatric patients but not in the assessment of general gastroenterology patients and not participating in gastroenterology call. First contact was made by e-mail correspondence, with e-mail and/or telephone follow-up as required between January 2004 and February 2005. Following compilation, the final list was verified with division heads by e-mail and telephone follow-up as required. The list of pediatric gastroenterologists was updated between March 2006 and May 2006 through e-mail contact and telephone follow-up with division heads and individual members as required.

\section{FTEs and clinical FTEs (2005)}

The job description for each pediatric gastroenterologist was obtained through e-mail correspondence, and telephone contact where required, with division heads or individual members where appropriate (eg, individuals working in nonacademic centres), with emphasis on job descriptions up until February 2005 (so as to correspond with population data). The committee first determined whether individuals worked full-time (ie, FTE) or part-time (ie, per cent FTE). The committee next determined the clinical component of each individual's job profile (clinical FTE). A clinicianspecialist was defined as an individual who devoted more than $75 \%$ of their time to clinical activities (1.0 clinical FTE), a clinician-teacher was considered to be a 0.5 clinical FTE and a clinician-scientist was defined as an individual who devoted less than $25 \%$ of their time to clinical activities ( 0.25 clinical FTE). When individuals worked in excess of the clinical allotment, an approximation of clinical FTEs was deemed appropriate. The results were tabulated, and estimated clinical FTEs for the pediatric patient population (zero to 17 years of age) for 2005 were compared.

Ratio of pediatric population to pediatric gastroenterologists (2005)

The ratio of pediatric population (zero to 17 years) to pediatric gastroenterologist by province was determined using the pediatric population data gathered from Statistics Canada for 2001 and 2005 and the data obtained by the pediatric committee on the total number of pediatric gastroenterologists across the country between January 2004 and February 2005. The results were tabulated and the data were compared.

\section{Sex distribution}

Workforce sex distribution was determined through the NASPGHAN and CAG membership databases, with e-mail and telephone confirmation when required. 
Age of the workforce, retirement plans, primary area of interest, and opinions on workforce adequacy and recruitment (2006)

The data were derived from a survey sent out by the CAG pediatric committee to the pediatric gastroenterology community between March 2006 and May 2006. A group e-mail was sent to all members of the Canadian pediatric gastroenterology community asking present age (or age range within five years), whether the member was planning to reduce his or her workload within the next five to 10 years, specific age the member planned to retire (or range within five to 10 years), primary area of interest of the member and whether the member felt that there were adequate numbers of pediatric gastroenterologists in the country. Follow-up e-mails were sent to individual members for clarification of data (when necessary) or for those members who did not respond to the initial group e-mail. In certain cases when information was not obtained by e-mail, individuals were contacted by telephone. The results were tabulated and the data were compared.

Status of pediatric gastroenterology trainees (past and present) A list of pediatric gastroenterology trainees (Canadian and international) who had completed (between 1998 and 2004), or were or would be completing (2005 to 2007) a Canadian pediatric gastroenterology fellowship program was compiled by the pediatric committee between July 2004 and February 2005 by contact with all subspecialty training program directors across Canada. Additional information obtained from program directors and postgraduate education offices included the country of origin of all trainees, confirmation of program completion and the destination of each trainee.

Between February 2005 and March 2005, trainees in a fellowship program were contacted by e-mail and asked a series of questions. The survey included requests to provide information regarding the fellowship training centre, current citizenship status and, where possible, details of future plans for employment, and especially whether the plans involved remaining in Canada or going abroad. Individuals who did not respond to the original request for information were contacted again, up to three times. The answers were collected and tabulated.

Final contact was made with all program directors and postgraduate offices by e-mail and telephone correspondence between March 2006 and May 2006 to verify collected data and obtain additional information when appropriate. Additional information was obtained on all fellows who had qualified by 2004 but were not included in the initial list or whose information was incomplete, and on all fellows who failed to respond to the initial survey but completed a fellowship in 2005 or would be completing a fellowship in 2006 or 2007.

\section{Present status of the pediatric gastroenterology fellowship} training programs

Program directors and postgraduate offices were contacted by e-mail and telephone follow-up between March 2006 and May 2006 to determine the duration of each fellowship program cycle, the source of funding, the number and duration of secure fellowship positions, the number of positions available for each program (Canadian and international fellows) and whether the program was Royal College-accredited.
Projected estimates of the pediatric gastroenterology workforce (2005 to 2026)

Utilizing data obtained on age of the workforce, age of planned retirement and the number of gastroenterologists who joined the Canadian pediatric gastroenterology workforce between 1996 and 2005, with inclusion of gastroenterology fellows who planned to join the workforce in 2006 and 2007, the committee estimated the rate of attrition or supplementation of the pediatric gastroenterology workforce from 2005 to 2026.

\section{Statistical analysis}

Descriptive statistics are presented. When appropriate, data are presented as the mean $\pm \mathrm{SD}$. The data were statistically compared with nonparametric tests, using the Mann-Whitney test. Statistical significance was $\mathrm{P}<0.05$. Statistical analyses were performed using GraphPad Prism 4 software (GraphPad Software Inc, USA).

\section{RESULTS}

Population distribution and population changes within Canada (3)

As of May 15, 2001, the total Canadian population was estimated at 30,007,095 individuals, of which 6,966,145, $7,373,550$ and $7,778,865$ were aged zero to 17 years, zero to 18 years and zero to 19 years, respectively (Table 1). All three age ranges were included because of the variable transitional age across provinces. In Canada, children zero to 17 years of age represented $23.2 \%$ of the population, with Quebec and Newfoundland and Labrador demonstrating the lowest proportion of children at $22 \%$ and $22 \%$, respectively, and the Northwest Territories and Nunavut demonstrating the highest proportion of children at $32 \%$ and $43 \%$, respectively.

Between 1994 and 2004, Canada was reported to have a population growth of approximately $1 \%$ per year. Of this, the rate of natural increase was $0.39 \%$ and the rate of net international migration was $0.61 \%$. The areas of Canada experiencing the highest growth rates included British Columbia, Ontario and Nunavut. The estimated Canadian population for 2005 was $32,270,507$. From 2001 to 2005, the pediatric population was estimated to have increased minimally, with an increase of less than $1 \%$ for each of the three age groups. The total estimated pediatric population (zero to 17 years of age) in Canada, as of July 2005, was 6,967,853 (Table 2) (3). As a result, the estimated pediatric population, as a percentage of the total Canadian population, declined by $1.6 \%$ (Table 2).

Provincial pediatric population distributions demonstrated variable changes in the size of the pediatric population. Ontario, Alberta, the Northwest Territories and Nunavut demonstrated growth in the pediatric population, with the increase ranging from $1.0 \%$ to $1.1 \%$. The Manitoban pediatric population remained stable over this period, whereas all other provinces demonstrated a $0.9 \%$ to $1.0 \%$ decline in the pediatric population. Again, Newfoundland and Labrador and Quebec demonstrated the lowest proportions of children, and the Northwest Territories and Nunavut demonstrated the highest proportions of children (Table 2).

\section{Status of the Canadian pediatric gastroenterology workforce (2005)}

As of February 2005, the CAG pediatric committee identified 64 practicing pediatric gastroenterologists across the country (including part-time physicians and physicians working in 
TABLE 1

Total Canadian population, pediatric population and provincial distributions as of May 15, 2001

\begin{tabular}{|c|c|c|c|c|}
\hline \multirow[b]{2}{*}{ Location } & \multicolumn{3}{|c|}{ Age groups (years) } & \multirow[b]{2}{*}{$\begin{array}{c}\text { Total } \\
\text { population, } \mathrm{n}\end{array}$} \\
\hline & $\begin{array}{c}0-17, n \\
(\% \text { of total) }\end{array}$ & $\begin{array}{c}0-18, n \\
(\% \text { of total) }\end{array}$ & $\begin{array}{c}0-19, n \\
(\% \text { of total) }\end{array}$ & \\
\hline Canada & $\begin{array}{r}6,966,145 \\
(23.21)\end{array}$ & $\begin{array}{r}7,373,550 \\
(24.57)\end{array}$ & $\begin{array}{r}7,778,865 \\
(25.92)\end{array}$ & $30,007,950$ \\
\hline $\begin{array}{l}\text { Newfoundland } \\
\text { and Labrador }\end{array}$ & $\begin{array}{r}112,440 \\
(21.92)\end{array}$ & $\begin{array}{r}120,500 \\
(23.49)\end{array}$ & $\begin{array}{r}128,220 \\
(24.99)\end{array}$ & 512,930 \\
\hline Prince Edward Island & $\begin{array}{l}32,845 \\
(24.27)\end{array}$ & $\begin{array}{l}34,870 \\
(25.77)\end{array}$ & $\begin{array}{l}36,875 \\
(27.25)\end{array}$ & 135,295 \\
\hline Nova Scotia & $\begin{array}{r}202,635 \\
(22.31)\end{array}$ & $\begin{array}{r}214,795 \\
(23.65)\end{array}$ & $\begin{array}{r}226,775 \\
(24.97)\end{array}$ & 908,005 \\
\hline New Brunswick & $\begin{array}{r}160,630 \\
(22.01)\end{array}$ & $\begin{array}{r}170,765 \\
(23.40)\end{array}$ & $\begin{array}{r}180,770 \\
(24.77)\end{array}$ & 729,500 \\
\hline Quebec & $\begin{array}{r}1,564,720 \\
(21.61)\end{array}$ & $\begin{array}{r}1,656,890 \\
(22.89)\end{array}$ & $\begin{array}{r}1,753,650 \\
(24.23)\end{array}$ & $7,237,480$ \\
\hline Ontario & $\begin{array}{r}2,701,830 \\
(23.67)\end{array}$ & $\begin{array}{r}2,853,700 \\
(25.01)\end{array}$ & $\begin{array}{r}3,002,165 \\
(26.31)\end{array}$ & $11,410,045$ \\
\hline Manitoba & $\begin{array}{r}282,930 \\
(25.27)\end{array}$ & $\begin{array}{r}298,530 \\
(26.66)\end{array}$ & $\begin{array}{r}314,140 \\
(28.05)\end{array}$ & $1,119,585$ \\
\hline Saskatchewan & $\begin{array}{r}255,265 \\
(26.07)\end{array}$ & $\begin{array}{r}270,740 \\
(27.65)\end{array}$ & $\begin{array}{r}285,540 \\
(29.16)\end{array}$ & 978,930 \\
\hline Alberta & $\begin{array}{r}752,000 \\
(25.27)\end{array}$ & $\begin{array}{r}796,590 \\
(26.77)\end{array}$ & $\begin{array}{r}840,550 \\
(28.25)\end{array}$ & $2,974,810$ \\
\hline British Columbia & $\begin{array}{r}869,945 \\
(22.26)\end{array}$ & $\begin{array}{r}923,765 \\
(23.63)\end{array}$ & $\begin{array}{r}976,350 \\
(24.98)\end{array}$ & $3,907,735$ \\
\hline Yukon Territories & $\begin{array}{r}7,460 \\
(26.02)\end{array}$ & $\begin{array}{r}7,905 \\
(27.57)\end{array}$ & $\begin{array}{r}8,325 \\
(29.03)\end{array}$ & 28,670 \\
\hline Northwest Territories & $\begin{array}{l}11,925 \\
(31.91)\end{array}$ & $\begin{array}{l}12,485 \\
(33.41)\end{array}$ & $\begin{array}{l}13,060 \\
(34.95)\end{array}$ & 37,360 \\
\hline Nunavut & $\begin{array}{l}11,525 \\
(43.09)\end{array}$ & $\begin{array}{l}12,015 \\
(44.92)\end{array}$ & $\begin{array}{l}12,445 \\
(46.53)\end{array}$ & 26,745 \\
\hline
\end{tabular}

Reproduced with permission from reference 3. Adapted from data derived from Census and Statistics Canada community profiles, catalogue \# 97F0003XCB2001001, Provincial Census 2001

nonacademic institutions, but excluding semiretired physicians 70 years of age and older with minimal clinical responsibilities) (Table 3), yielding an estimate of 9.2 pediatric gastroenterologists per million pediatric population (zero to 17 years old). Of the 11 physicians working part-time, eight were female $(73 \%)$. No pediatric gastroenterologist was present on Prince Edward Island, where pediatric patients requiring specialized gastroenterological care were referred to Halifax, Nova Scotia. One physician was present in New Brunswick and was expected to provide both general pediatric and gastroenterology support (0.5 FTEs for each discipline) and refer patients with complex gastroenterology disorders to Halifax. Thus, for subsequent analyses, patients and physicians from the three Maritime provinces were analyzed together. No pediatric gastroenterologists were stationed in the Yukon, the Northwest Territories or Nunavut, where pediatric gastroenterology patients are typically referred to the western provinces, Ontario and Quebec. Populations from these areas were not included in the analyses due to the difficulty in determining population numbers and referral centres.
TABLE 2

Estimates of total Canadian population, pediatric population and provincial distributions as of 2005

\begin{tabular}{|c|c|c|c|c|}
\hline \multirow[b]{2}{*}{ Location } & \multicolumn{3}{|c|}{ Age groups (years) } & \multirow[b]{2}{*}{$\begin{array}{c}\text { Total } \\
\text { population, } n\end{array}$} \\
\hline & $\begin{array}{c}0-17, n \\
\text { (\% of total) }\end{array}$ & $\begin{array}{c}0-18, n \\
\text { (\% of total) }\end{array}$ & $\begin{array}{c}0-19, n \\
(\% \text { of total) }\end{array}$ & \\
\hline Canada & $\begin{array}{r}6,967,853 \\
(21.59)\end{array}$ & $\begin{array}{r}7,406,794 \\
(22.95)\end{array}$ & $\begin{array}{r}7,831,263 \\
(24.26)\end{array}$ & $32,270,507$ \\
\hline $\begin{array}{l}\text { Newfoundland } \\
\text { and Labrador }\end{array}$ & $\begin{array}{r}101,458 \\
(19.66)\end{array}$ & $\begin{array}{r}108,623 \\
(21.05)\end{array}$ & $\begin{array}{r}115,479 \\
(22.38)\end{array}$ & 515,961 \\
\hline Prince Edward Island & $\begin{array}{l}30,529 \\
(25.55)\end{array}$ & $\begin{array}{l}32,691 \\
(23.66)\end{array}$ & $\begin{array}{l}34,790 \\
(25.18)\end{array}$ & 138,113 \\
\hline Nova Scotia & $\begin{array}{r}189,490 \\
(20.20)\end{array}$ & $\begin{array}{r}202,546 \\
(21.59)\end{array}$ & $\begin{array}{r}215,202 \\
(22.94)\end{array}$ & 937,889 \\
\hline New Brunswick & $\begin{array}{r}150,784 \\
(20.05)\end{array}$ & $\begin{array}{r}161,001 \\
(21.40)\end{array}$ & $\begin{array}{r}170,800 \\
(22.71)\end{array}$ & 752,006 \\
\hline Quebec & $\begin{array}{r}1,538,081 \\
(20.24)\end{array}$ & $\begin{array}{r}1,631,660 \\
(21.47)\end{array}$ & $\begin{array}{r}1,721,751 \\
(22.66)\end{array}$ & $7,598,146$ \\
\hline Ontario & $\begin{array}{r}2,777,653 \\
(22.14)\end{array}$ & $\begin{array}{r}2,948,822 \\
(23.51)\end{array}$ & $\begin{array}{r}3,115,387 \\
(24.48)\end{array}$ & $12,541,410$ \\
\hline Manitoba & $\begin{array}{r}282,600 \\
(23.99)\end{array}$ & $\begin{array}{r}299,696 \\
(25.45)\end{array}$ & $\begin{array}{r}316,574 \\
(26.88)\end{array}$ & $1,177,556$ \\
\hline Saskatchewan & $\begin{array}{r}240,950 \\
(24.23)\end{array}$ & $\begin{array}{r}256,708 \\
(25.82)\end{array}$ & $\begin{array}{r}271,942 \\
(27.35)\end{array}$ & 994,126 \\
\hline Alberta & $\begin{array}{r}763,440 \\
(23.44)\end{array}$ & $\begin{array}{r}811,965 \\
(24.93)\end{array}$ & $\begin{array}{r}858,763 \\
(26.26)\end{array}$ & $3,256,816$ \\
\hline British Columbia & $\begin{array}{r}860,899 \\
(20.23)\end{array}$ & $\begin{array}{r}919,356 \\
(21.60)\end{array}$ & $\begin{array}{r}975,089 \\
(22.91)\end{array}$ & $4,254,522$ \\
\hline Yukon Territories & $\begin{array}{r}7,067 \\
(23.12)\end{array}$ & $\begin{array}{r}7,566 \\
(24.41)\end{array}$ & $\begin{array}{r}8,058 \\
(26.00)\end{array}$ & 30,988 \\
\hline Northwest Territories & $\begin{array}{r}12,612 \\
(29.34)\end{array}$ & $\begin{array}{l}13,294 \\
(30.92)\end{array}$ & $\begin{array}{r}13,980 \\
(32.52)\end{array}$ & 42,982 \\
\hline Nunavut & $\begin{array}{l}12,290 \\
(40.97)\end{array}$ & $\begin{array}{l}12,866 \\
(42.89)\end{array}$ & $\begin{array}{l}13,448 \\
(44.83)\end{array}$ & 29,992 \\
\hline
\end{tabular}

Reproduced with permission from reference 3. Adapted from CANSIM Table 051-0001. Population estimates are based on data for 2004 published by Statistics Canada, July 1, 2005

FTEs and clinical FTEs (2005)

Thirty-six per cent of the Canadian pediatric gastroenterology workforce was stationed in Ontario, 25\% in Quebec, 17\% in Alberta and 9\% in British Columbia, with the remaining 11\% of individuals scattered among the Maritime provinces, Manitoba, Saskatchewan and Newfoundland (Table 3). Translating these numbers into FTEs and clinical FTEs, this corresponded to an actual workforce that was lower by $9 \%$ and $35 \%$, respectively (Table 3). However, no change was observed in the smaller provinces that were limited to one or two physicians per province due to patient pressures associated with limited numbers of physicians. The Alberta Children's Hospital (Calgary, Alberta) demonstrated the largest decrease from number of practicing physicians employed to available clinical FTEs (52\%), largely due to several members working part-time or having extensive administrative responsibilities. Ontario demonstrated the second largest decrease $(37 \%)$, followed by British Columbia (35\%) and Quebec (30\%). Centres with smaller complements of physicians, including Halifax (Nova Scotia), Kingston (Ontario), the Children's Hospital of 
TABLE 3

Total number and geographic distribution of the Canadian pediatric gastroenterology workforce, full-time equivalents (FTEs) and clinical FTEs, 2005

\begin{tabular}{|c|c|c|c|}
\hline Location/centre & $\begin{array}{c}\text { Total } \\
\text { pediatric } \\
\text { Gls, } n\end{array}$ & $\begin{array}{c}\text { FTEs, } \\
\mathbf{n}\end{array}$ & $\begin{array}{l}\text { Clinical } \\
\text { FTEs, } \mathbf{n}\end{array}$ \\
\hline Canada & 64 & 58.1 & 41.85 \\
\hline \multicolumn{4}{|l|}{ Newfoundland and Labrador } \\
\hline $\begin{array}{l}\text { Janeway Children's Health } \\
\text { and Rehabilitation Centre (St John's) }\end{array}$ & 1 & 1 & 1 \\
\hline \multicolumn{4}{|l|}{ New Brunswick } \\
\hline $\begin{array}{l}\text { Saint John Regional Hospital* } \\
\text { (Saint John) }\end{array}$ & 1 & 0.5 & 0.5 \\
\hline \multicolumn{4}{|l|}{ Nova Scotia } \\
\hline IWK Health Centre (Halifax) & 3 & 3 & $2.5(2.25)^{\pi}$ \\
\hline Quebec & 16 & 15.5 & 11.25 \\
\hline Hôpital Sainte-Justine (Montreal) ${ }^{\dagger}$ & 9 & 9 & 5.5 \\
\hline $\begin{array}{l}\text { Montreal Children's Hospital }{ }^{\dagger} \\
\text { (Montreal) }\end{array}$ & 4 & 3.5 & 2.75 \\
\hline $\begin{array}{l}\text { Sainte-Foy Centre Hospitalier } \\
\text { de l'Universitaire Laval (Sainte-Foy) }\end{array}$ & 2 & 2 & 2 \\
\hline $\begin{array}{l}\text { Sherbrooke University } \\
\text { Hospital Centre (Sherbrooke) }\end{array}$ & 1 & 1 & 1 \\
\hline Ontario & 23 & 20.75 & 14.4 \\
\hline The Hospital for Sick Children (Toronto) & 12 & 11.1 & 5.6 \\
\hline Other $\ddagger$ & 4 & 2.65 & 2.4 \\
\hline $\begin{array}{l}\text { McMaster Children's Hospital } \\
\text { (Hamilton) }\end{array}$ & 3 & 3 & 3 \\
\hline Kingston General Hospital (Kingston) & 1 & 1 & $0.5(0.25)^{\pi}$ \\
\hline CHEO (Ottawa) & 2 & 2 & $1.9(1.4)^{\pi}$ \\
\hline $\begin{array}{l}\text { Children's Hospital of } \\
\text { Western Ontario (London) }{ }^{\S}\end{array}$ & 1 & 1 & 1 \\
\hline \multicolumn{4}{|l|}{ Manitoba } \\
\hline Winnipeg Children's Hospital (Winnipeg) & y) 2 & 2 & 2 \\
\hline \multicolumn{4}{|l|}{ Saskatchewan } \\
\hline Royal University Hospital (Saskatoon) & 1 & 1 & 1 \\
\hline Alberta & 11 & 9.35 & 5.3 \\
\hline Alberta Children's Hospital (Calgary) & 6 & 4.6 & 2.75 \\
\hline Stollery Children's Hospital (Edmonton) & 5 & 4.75 & 2.55 \\
\hline \multicolumn{4}{|l|}{ British Columbia } \\
\hline $\mathrm{BCCH}^{*}$ (Vancouver) & 6 & 5 & $3.9^{* *}(3.75)$ \\
\hline
\end{tabular}

Only physicians actively involved in pediatric gastroenterology and/or nutrition patient care at the time of the survey were included. *Includes a physician at each institution who provided both general pediatric support $(0.5$ and 0.7 FTEs, respectively) and gastroenterology care; tThree physicians $\geq 70$ years of age who were working $\leq 0.1$ FTE and did not occupy official positions in gastroenterology at the time of the analysis were excluded; IIncludes physicians in nonacademic practice in Ontario (Scarborough Centenary Hospital, North York General Hospital and Joseph Brant Memorial Hospital [Burlington]). Two clinical nutritionists not involved in assessment of general gastroenterology patients and not participating in gastroenterology call (Stollery Children's Hospital and North York General Hospital) were included; $\S$ An adult gastroenterologist in London, Ontario, who was seeing both pediatric and adult gastroenterology patients at the University Hospital was excluded; TProvides the clinical FTEs (as estimated by physician) with the FTEs in parentheses reflective of the FTEs in accordance with job descriptions. BCCH British Columbia Children's Hospital; CHEO Children's Hospital of Eastern Ontario; GI Gastroenterologist

Western Ontario (London, Ontario) and the British Columbia Children's Hospital (BCCH) (Vancouver, British Columbia) noted an inability of division members to maintain job profiles in accordance with job descriptions due to patient care responsibilities.
TABLE 4

Estimates of the Canadian pediatric population (zero to 17 years), provincial distributions, the pediatric population per gastroenterologist, per full-time equivalent (FTE) and per clinical FTE, as of February 2005

\begin{tabular}{lrcrc}
\hline Location & $\begin{array}{c}\text { Population, } \\
\mathbf{0 - 1 7} \text { years, } \mathbf{n}\end{array}$ & $\begin{array}{c}\text { Population } \\
\text { per GI } \\
\text { physician, } \mathbf{n}\end{array}$ & $\begin{array}{c}\text { Population } \\
\text { per GI } \\
\text { FTE, } \mathbf{n}\end{array}$ & $\begin{array}{c}\text { Population } \\
\text { per GI clinical } \\
\text { FTE, n }\end{array}$ \\
\hline Canada & $6,967,853$ & 108,872 & 119,928 & 166,495 \\
Newfoundland & 101,458 & 101,458 & 101,458 & 101,458 \\
$\quad$ and Labrador & & & & \\
Maritime provinces & 370,803 & 92,701 & 105,944 & 123,601 \\
Quebec & $1,538,081$ & 96,130 & 99,231 & 136,718 \\
Ontario & $2,777,653$ & 120,768 & 133,863 & 192,893 \\
Manitoba & 282,600 & 141,300 & 141,300 & 141,300 \\
Saskatchewan & 240,950 & 240,950 & 240,950 & 240,950 \\
Alberta & 763,440 & 69,404 & 81,651 & 144,045 \\
British Columbia & 860,899 & 143,483 & 172,180 & 220,743 \\
\hline
\end{tabular}

Maritime provinces include Prince Edward Island, New Brunswick and Nova Scotia. Population estimates are based on data for 2004 from reference 3 (Statistics Canada estimates of total Canadian population, pediatric population and provincial distributions, published July 1, 2005, CANSIM Table 051 0001). Gl Gastrointestinal

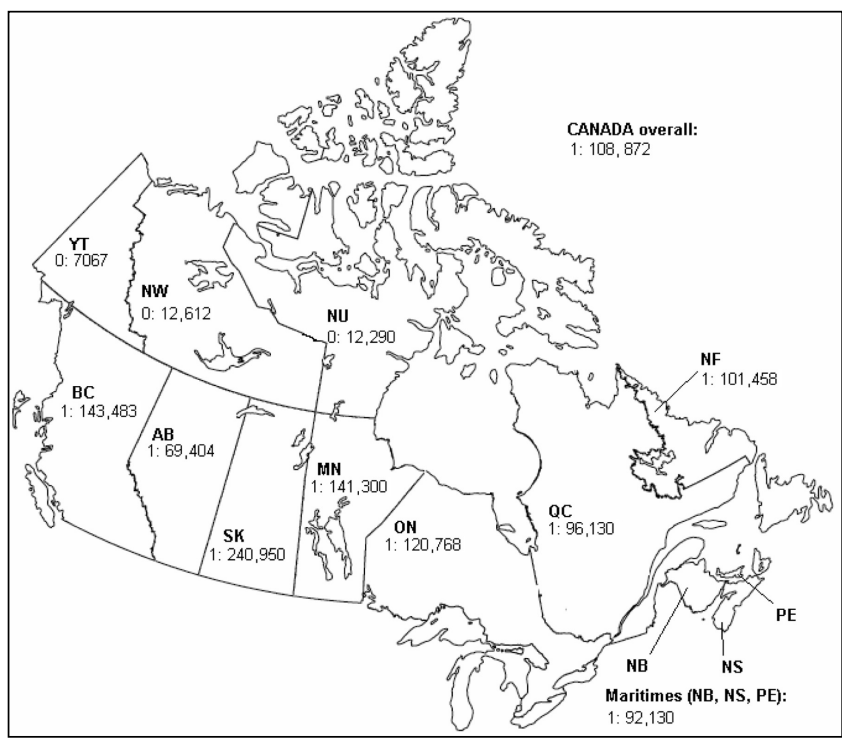

Figure 1) Provincial ratios of pediatric gastroenterologists to the estimated pediatric population (zero to 17 years), determined as of February 2005. AB Alberta; BC British Columbia; MN Manitoba; NB New Brunswick; NF Newfoundland and Labrador; NS Nova Scotia; NU Nunavut; NW Northwest Territories; ON Ontario; PE Prince Edward Island; QC Quebec; SK Saskatchewan; YT Yukon Territories. Reproduced with permission from reference 3

Ratio of pediatric population (overall, by province and by centre): pediatric gastroenterologist, FTEs and clinical FTEs, 2005

The ratio of Canadian pediatric population (zero to 17 years of age) to pediatric gastroenterologist was estimated at 108,872:1 (Table 4 and Figure 1). The ratio of pediatric population to physician ratio varied markedly across the country, with Alberta demonstrating the lowest ratio $(69,404: 1)$ followed by the Maritime provinces and Quebec; Saskatchewan demonstrated the highest ratio $(240,950: 1)$, followed by British Columbia and Manitoba (Table 4 and Figure 1). 
TABLE 5

Sex distribution of pediatric gastroenterologists by province and city, as of February 2005

\begin{tabular}{lc}
\hline Location & Sex ratio (F:M), $\mathbf{n}$ \\
\hline Canada & $32: 32$ \\
Newfoundland and Labrador (St John's) & $0: 1$ \\
Maritime provinces* & $2: 2$ \\
Quebec & $9: 7$ \\
Montreal & $8: 5$ \\
Sherbrooke & $0: 1$ \\
Sainte-Foy & $1: 1$ \\
Ontario & $13: 10$ \\
Toronto & $9: 6$ \\
Hamilton & $2: 1$ \\
Burlington & $1: 0$ \\
Kingston & $0: 1$ \\
Ottawa & $1: 1$ \\
London & $0: 1$ \\
Manitoba (Winnipeg) & $1: 1$ \\
Saskatchewan (Saskatoon) & $0: 1$ \\
Alberta & $7: 4$ \\
Edmonton & $3: 2$ \\
Calgary & $4: 2$ \\
British Columbia (Vancouver) & $0: 6$
\end{tabular}

*Maritime provinces include Nova Scotia, Prince Edward Island and New Brunswick. F Female; M Male

Because the total number of pediatric gastroenterologists failed to account for part-time staff, staff with largely administrative roles (eg, department heads), clinician scientists and clinical teachers, the committee chose to determine the total number of FTEs and estimated clinical FTEs, and presented the data accordingly (Table 4). Representing the data in this manner was associated with a marked change in pediatric population to physician ratios across the country, with the exception of centres where limited or no time protection from patient care was provided. When consideration was given to clinical FTEs, the overall pediatric population to physician ratio increased 1.53 -fold to 166,495:1 (Table 4). Alberta was observed to have the highest increase, with a 2.07-fold increase in the pediatric patient to physician ratio, followed by New Brunswick (two-fold), British Columbia (1.53-fold), Ontario and Quebec (1.4-fold), and the Maritime provinces (1.33-fold). The ratios presented are reflective of clinical FTEs of each centre that, in some instances, were affected by patient care pressures and did not take into account FTEs in accordance with job descriptions. This was especially evident in the smaller and midsize institutions that appeared less able to protect physicians (clinician scientists) from the clinical workload than larger institutions, resulting in less time committed to research activities.

\section{Workforce sex and geographic distribution}

Female gastroenterologists accounted for $50 \%$ of the Canadian pediatric gastroenterology workforce (Table 5). While Ontario and Quebec had the greatest absolute number of female physicians in the workforce, female physicians in New Brunswick and Alberta accounted for $100 \%$ and $64 \%$ of the local gastroenterology workforce, respectively, followed by Ontario $(57 \%)$ and Quebec (56\%). In contrast, British Columbia,
Saskatchewan, and Newfoundland and Labrador only had male physicians.

Age of the workforce, retirement plans, primary area of interest, and opinions on workforce adequacy and recruitment (2006)

At the time of follow-up to the survey, the workforce had increased from 64 to 67 pediatric gastroenterologists, with recruitment of one physician each to the Children's Hospital of Eastern Ontario (Ottawa, Ontario), McMaster Children's Hospital (Hamilton, Ontario) and Hôpital Sainte-Justine (Montreal, Quebec), such that female gastroenterologists accounted for $52 \%$ of the workforce. The present data were derived from responses provided by 61 of 67 members (91\%) of the Canadian pediatric gastroenterology workforce. The mean age \pm SD of the workforce, as of May 2006, was $45.6 \pm 8.8$ years. Female gastroenterologists were significantly younger than their male colleagues $(41.4 \pm 6.7$ years versus $49.9 \pm 8.6$ years, respectively; $\mathrm{P}=0.0002$ ).

The planned mean age of retirement, as indicated by the workforce, was $62.7 \pm 4.3$ years. Male gastroenterologists indicated that they planned to retire at an older age than their female colleagues $(64.2 \pm 3.3$ years compared with $60.8 \pm 4.4$ years, respectively; $\mathrm{P}=0.02$ ). Taking into consideration the present age of the workforce, the mean number of years to planned retirement was $17 \pm 8.3$ years. Although female gastroenterologists planned to retire at a younger age, given that they were younger than their male colleagues, they would remain in the workforce for a longer period of time $(19.6 \pm 7.7$ years compared with $14.3 \pm 8.0$ years, respectively; $\mathrm{P}=0.02$ ).

Seventy-seven per cent of gastroenterologists identified themselves as primarily luminal gastroenterologists, $15 \%$ as hepatologists and $8 \%$ as clinical nutritionists. While this distinction had been made, most physicians participated in the care of children in all three areas. Fifty of 61 respondents $(82 \%)$ provided information on their principal areas of interest and $33 \%$ on secondary areas of interest. While the majority of respondents identified inflammatory bowel disease (IBD) as their principal area of interest (34\%), other main areas of interest included upper gastrointestinal disorders (acid peptic disease and celiac disease) (14\%), functional gastrointestinal and motility disorders (12\%), liver disorders (viral hepatitis, biliary atresia, portal hypertension, nonalcoholic fatty liver, transplantation) $(18 \%)$, clinical nutrition $(10 \%)$, medical education (4\%), allergy (2\%), enteric infection (2\%), obesity $(2 \%)$ and general gastroenterology (2\%). Secondary areas of interest included quality of life and therapeutics in IBD, cystic fibrosis, eosinophilic disease, endoscopy or capsule endoscopy, neonatal nutrition, short bowel syndrome and intestinal failure, gastrointestinal oncology, medical education, outcomes research and community gastroenterology.

Fifty-six of 61 respondents (92\%) provided information on workforce adequacy. Forty-nine of 56 respondents (88\%) indicated that the present workforce was inadequate to support the current demands of the Canadian pediatric population, while $7 \%$ were unsure. Just $5 \%$ indicated that the present workforce was sufficient to support the demands of the pediatric gastroenterology community.

Past and present trainees

Between 1998 and 2004, the seven Canadian pediatric gastroenterology fellowship training programs (six were Royal 
TABLE 6

Profile of pediatric gastroenterology trainees across Canada, 1998 to 2004, and subsequent place of employment

\begin{tabular}{|c|c|c|c|c|c|}
\hline Hospital & $\begin{array}{c}\text { Pediatric } \\
\text { gastroenterology } \\
\text { fellows, } n\end{array}$ & $\begin{array}{l}\text { Canadian } \\
\text { fellows, } n\end{array}$ & $\begin{array}{l}\text { International } \\
\text { fellows, } n\end{array}$ & $\begin{array}{c}\text { Canadian } \\
\text { gastroenterology } \\
\text { positions }(n)\end{array}$ & $\begin{array}{c}\text { International } \\
\text { gastroenterology } \\
\text { positions (n) }\end{array}$ \\
\hline British Columbia Children's Hospital & 4 & 1 & - & Ontario (1) & - \\
\hline \multirow{2}{*}{ (Vancouver, British Columbia) } & - & - & - & - & Europe (1) \\
\hline & - & - & - & - & South Asia (1) \\
\hline \multirow{2}{*}{ Alberta Children's Hospital (Calgary, Alberta) } & - & - & - & - & Middle East (4) \\
\hline & - & - & - & - & South Asia (1) \\
\hline Stollery Children's Hospital (Edmonton, Alberta) & 0 & 0 & 0 & 0 & 0 \\
\hline \multirow[t]{5}{*}{ The Hospital for Sick Children (Toronto, Ontario) } & 31 & $12^{\dagger+1} 1^{\ddagger}$ & - & Maritime provinces (4) & USA (1) \\
\hline & - & - & - & Ontario $(4)^{\S} \pi$ & - \\
\hline & - & - & - & - & South America (2) \\
\hline & - & - & - & - & Middle East (3) \\
\hline & - & - & - & - & East Asia (1) \\
\hline \multirow[t]{2}{*}{ Montreal Children's Hospital (Montreal, Quebec) } & 2 & 1 & - & Quebec (1) & - \\
\hline & & - & 1 & - & Middle East (1) \\
\hline \multirow[t]{3}{*}{ Hôpital Sainte-Justine (Montreal, Quebec) } & $7^{*}$ & $3+1^{\ddagger}$ & - & Quebec (1) & USA (2) \\
\hline & - & - & - & Ontario (1) & - \\
\hline & - & - & 3 & - & Europe (3) \\
\hline \multirow[t]{2}{*}{ McMaster Children's Hospital (Hamilton, Ontario) } & 5 & 1 & - & Ontario $(1)^{\S}$ & - \\
\hline & - & - & 4 & - & Middle East (4) \\
\hline
\end{tabular}

Information on pediatric gastroenterology fellows who trained in a Canadian pediatric gastroenterology fellowship program from 1998 to 2004 obtained from program directors and postgraduate education offices across Canada from July 2004 to May 2006. Europe included the United Kingdom, France and Switzerland. South and East Asia included India and Hong Kong. The Middle East included Israel and Saudi Arabia. South America included Argentina. Australasia included Australia and New Zealand. *One adult gastroenterology fellow who trained at Hôpital Sainte-Justine for one year was not included in the analysis; ${ }^{\dagger}$ One Canadian gastroenterology fellow undertook further research training and one fellow joined a nongastroenterology discipline (and were therefore excluded from the gas-

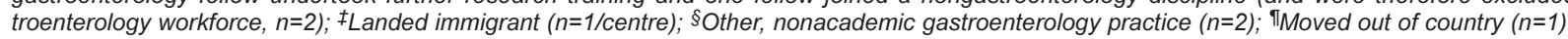

College-accredited) trained 60 pediatric gastroenterologists (Table 6). Twenty-four trainees $(40 \%)$ were either Canadian citizens $(n=22)$ or landed immigrants $(n=2)$, and 36 trainees were international fellows (Table 6). Following qualification, five Canadian trainees (8\%) did not enter the Canadian pediatric gastroenterology workforce, either due to pursuit of further training and acceptance of a staff position outside Canada $(n=4)$ or due to joining a nongastroenterology discipline $(n=1)$. An additional gastroenterologist trained in Canada vacated an academic staff position within Canada to pursue a career in the United States. Thus, over the six-year period, of the 24 trained gastroenterology fellows who could potentially have joined the workforce, only 18 individuals joined and remained part of the Canadian gastroenterology workforce (ie, $75 \%$ of potential candidates and $30 \%$ of all trainees). Eighty-nine per cent of those individuals entering the Canadian pediatric gastroenterology workforce joined academic institutions.

Information was obtained on all 24 pediatric gastroenterology fellows in the Canadian gastroenterology fellowship training programs in 2005. Twelve trainees returned fully completed surveys, and information on the remaining 12 trainees was obtained through program directors and postgraduate education offices (Table 7). The 24 gastroenterology fellows were distributed between programs in Ontario (42\%), British Columbia (29\%), Quebec (17\%) and Alberta (13\%). Five of the trainees were Canadian citizens and an additional two individuals had dual Israeli and Canadian citizenship (29\%) (Table 7). In addition, three trainees obtained landed immigrant status, increasing the number of eligible trainees for Canadian positions to $42 \%$.

Of the five pediatric gastroenterology fellows completing a fellowship program in 2005, three landed immigrants entered the Canadian gastroenterology workforce by obtaining academic positions $(60 \%)$, one Canadian citizen went into private practice and one international trainee returned home to a clinical gastroenterology position (Table 7, Figure 2). Of the seven fellows scheduled to complete their training in 2006, $29 \%$ were Canadian citizens who planned to join the Canadian gastroenterology workforce (Figure 2). One international fellow pursuing additional research training expressed an interest in joining the Canadian gastroenterology workforce should an employment opportunity arise. The remaining international fellows $(57 \%)$ planned to return to their country of 
TABLE 7

Profile of the 2005 pediatric gastroenterology trainees across Canada

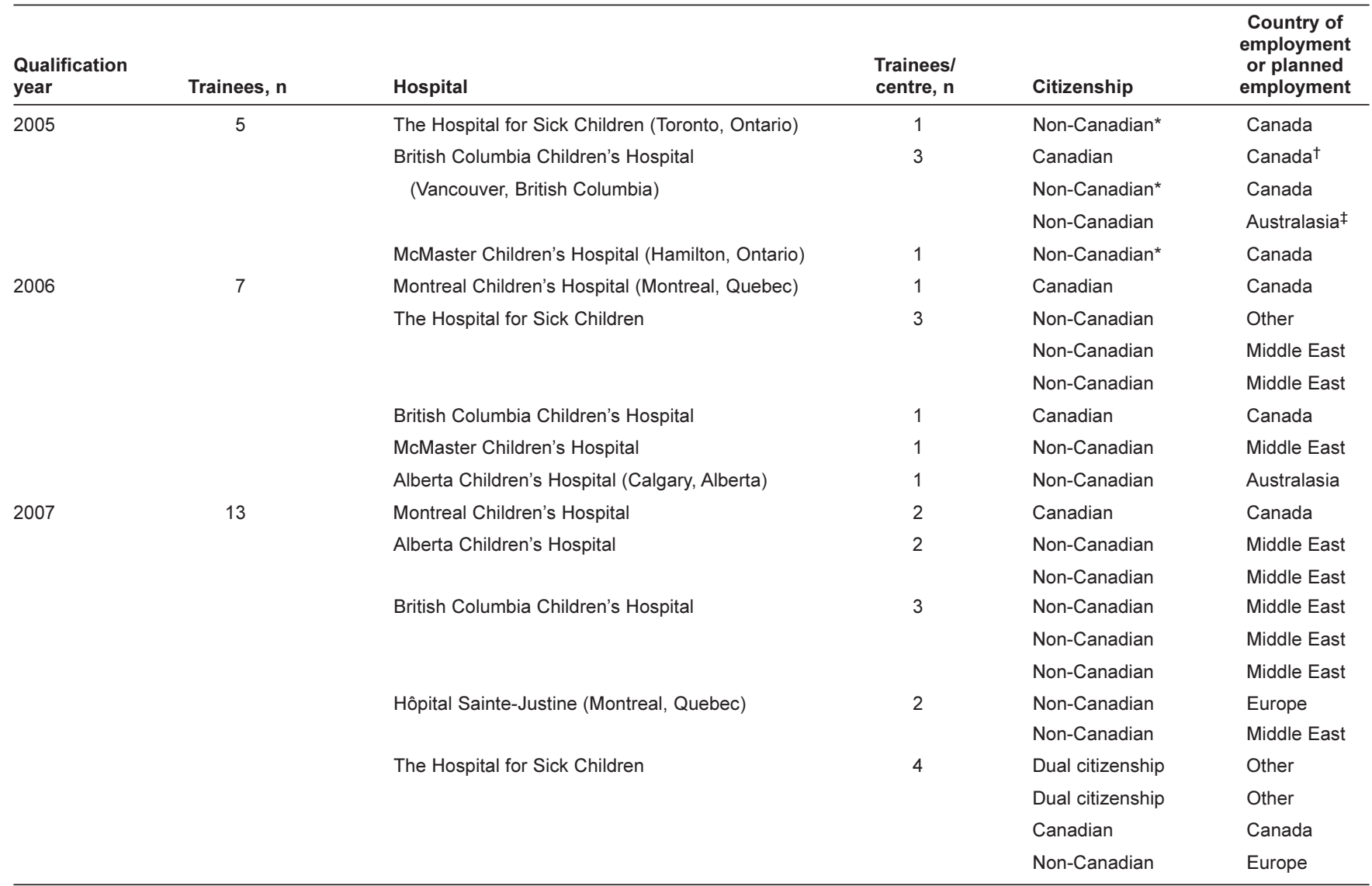

Information on pediatric gastroenterology fellows in Canadian fellowship programs in 2005 obtained from trainees ( $n=12$ ), as well as from program directors and postgraduate offices ( $n=12$ ), across Canada from July 2004 to May 2006. 'Other' plans included intending to or considering remaining in Canada following completion of research training. Non-Canadians included individuals from Australia and New Zealand, France, Switzerland, Germany, India, Israel, Egypt, Kuwait, Libya,

Saudi Arabia and Oman. *Landed immigrants; †Private practice; $¥$ Would have remained in Canada if the right opportunity had become available.

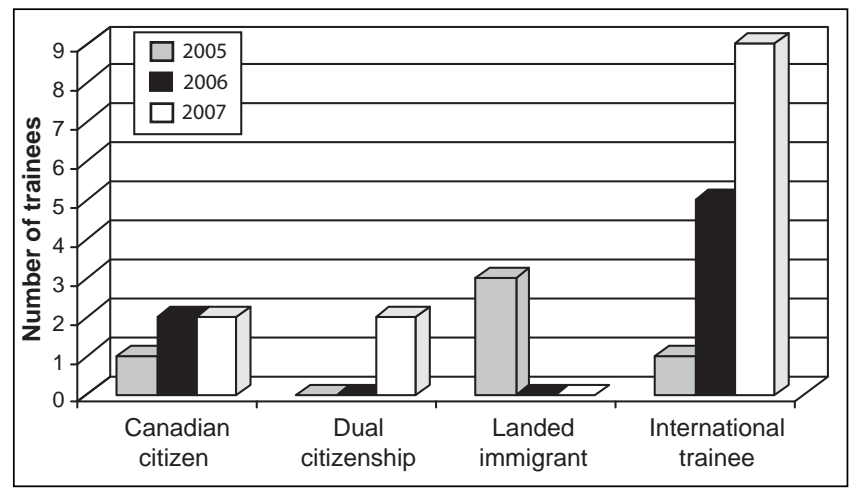

Figure 2) Number of pediatric gastroenterology fellows in a pediatric gastroenterology fellowship program across Canada who completed training in 2005 or would complete training in 2006 or 2007, along with their corresponding citizenship status

origin. Of the 13 fellows scheduled to complete their clinical training in 2007,15\% were Canadian citizens who wished to remain in Canada. An additional 15\% with dual Israeli and Canadian citizenship planned to undertake further research training and would consider remaining in Canada should a job opportunity arise (Figure 2). The international trainees intended to return to their countries of origin.

Status of pediatric gastroenterology fellowship training programs (May 2006)

As of May 2006, six Royal College-accredited gastroenterology fellowship training programs were identified, in addition to one nonaccredited training program (Table 8). Provincial Ministries of Health (MOHs) or the Regie de l'Assurance Maladie du Québec, the Quebec equivalent, were identified as the main source of funding for Canadian or landed immigrant pediatric residents entering their institutional fellowship programs at the R4 and R5 level in Alberta, Toronto, Ontario and Quebec. Funding support was only available for two years, with the third year of training subject to competitive external funding sought from organizations such as CAG or the Crohn's and Colitis Foundation of Canada or where applicable, through on-call payment (Hospital for Sick Children [Toronto]). $\mathrm{MOH}$ funding was also available at $\mathrm{BCCH}$; however, the support was not restricted to a Canadian or landed immigrant pediatric resident, but included support for an international pediatric graduate for three years. No $\mathrm{MOH}$ funding was available for the McMaster Children's Hospital fellowship program. 
TABLE 8

Status of Canadian gastroenterology fellowship programs, May 2006

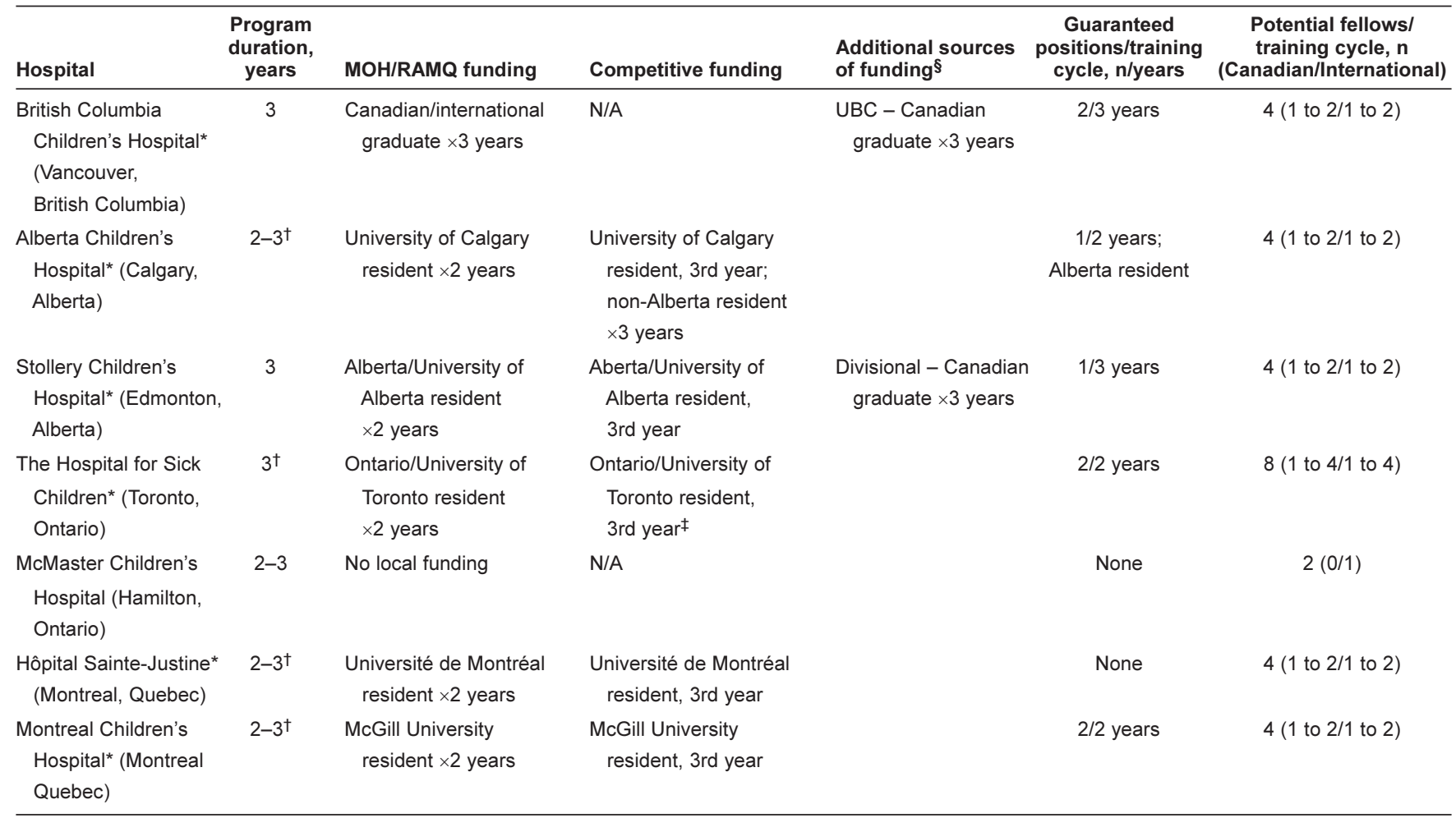

Information on Canadian fellowship programs was obtained from program directors and postgraduate offices across Canada from March 2006 to May 2006 . With the exception of one potential position at the University of British Columbia (UBC), international trainees accepted to all Canadian programs require external funding. *Royal College-accredited; Third year of training subject to competitive external funding (Canadian Association of Gastroenterology, and Crohn's and Colitis Foundation of Canada); ¥Supplement salary with on-call payment; MOH Ministry of Health; N/A not applicable; RAMQ Régie de l'Assurance Maladie du Québec

Competitive funding support was required by the Alberta Children's Hospital for non-University of Calgary residents for the full three-year duration of the program, whereas Stollery Children's Hospital and BCCH were each able to fund one Canadian trainee for three years through a divisional resource or a University of British Columbia-funded position, respectively. An additional source of non- $\mathrm{MOH}$ funds was also available through the departments of pediatrics at some institutions. However, the committee was unable to further clarify this source of funding. All programs required external funding support for all international graduates for the three year duration of training, including $\mathrm{BCCH}$, once the $\mathrm{MOH}$ position was occupied.

The number of guaranteed funded positions varied among centres, with Stollery Children's Hospital and BCCH having one and two positions for a three-year cycle, respectively, whereas all other accredited programs had one position (Alberta Children's Hospital) or two positions (Hospital for Sick Children and Montreal Children's Hospital [Quebec]) for a two-year cycle. McMaster Children's Hospital and Hôpital Sainte-Justine had no guaranteed positions. The number of potential gastroenterology trainees varied between centres, ranging from two to eight trainees per three-year cycle at each centre.

Projected estimates of the future Canadian pediatric gastroenterology workforce (2026)

In 2005, the 64 pediatric gastroenterologists across Canada were providing 42 clinical FTEs (or 1.5 physicians provided one clinical FTE). Taking into consideration the 2006 survey, in which 40 of the above members planned to retire within the next 20 years (mean number of years to planned retirement $16.95 \pm 8.31$ years) and the associated reduction in clinical FTEs, the workforce was projected to decrease by 26 clinical FTEs in 2026. This projection translated into a reduction rate of two physicians per year or 1.3 clinical FTEs per year (Figures $3 \mathrm{~A}$ and $3 \mathrm{~B})$.

Considering that the number of Canadian pediatric gastroenterologists increased from 48 members in 1996 (2) to 64 members in 2005 to 67 members as of May 2006, the workforce increased by 1.8 and 1.9 pediatric gastroenterologists per year, respectively, or by 1.2 and 1.3 clinical FTEs per year, respectively. Taking into consideration that two Canadian trainees would have entered the workforce as of July 2006 and the possibility of an additional two Canadians entering the workforce following completion of their programs in 2007, the workforce would increase to 71 members or by two pediatric gastroenterologists per year (1.3 clinical FTEs per year) (Figure $3 \mathrm{~A})$. Furthermore, inclusion of international trainees who were considering joining the workforce, should appropriate positions become available when their training was complete $(n=1,2006 ; n=2,2007)$, would increase the workforce to 74 members or 2.4 pediatric gastroenterologists per year (1.6 clinical FTEs per year) (Figure 3B).

Using the above calculations to estimate Canadian workforce projections to 2026 indicated that the present rate of acquisition of Canadian pediatric gastroenterologists of 1.3 to 1.6 clinical FTEs per year will either just maintain the status 


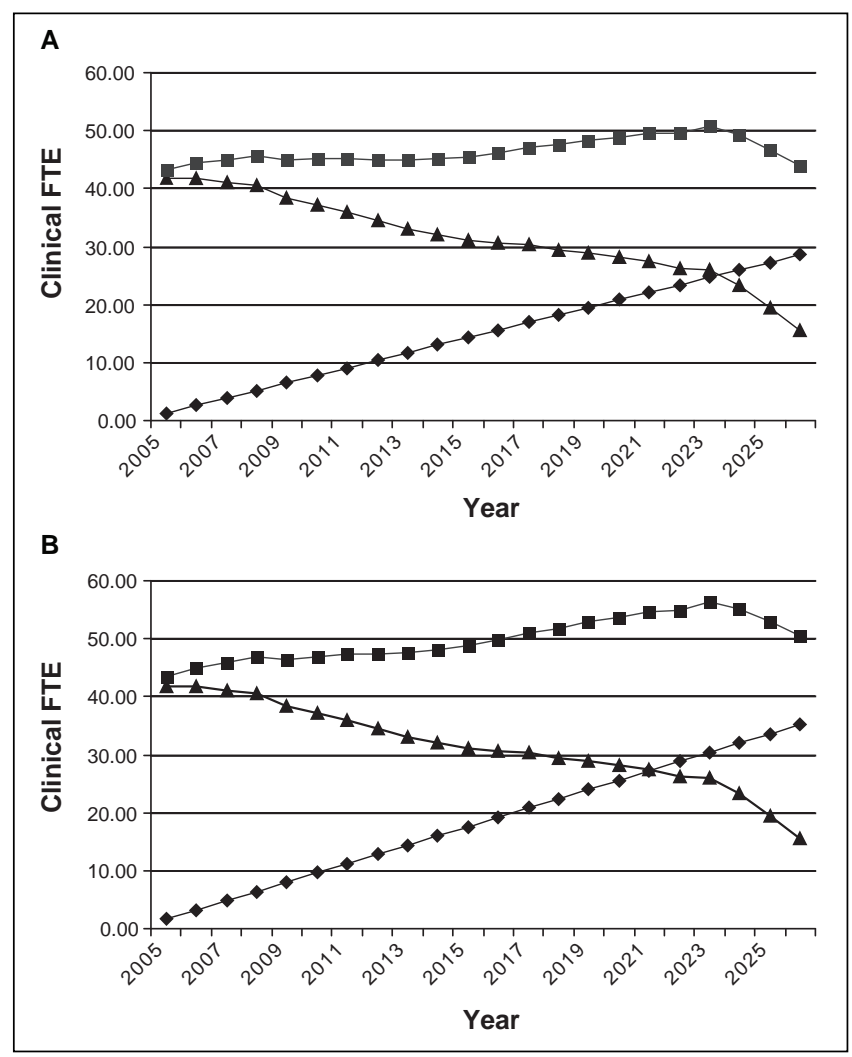

Figure 3) A Projected reduction in clinical full-time equivalents (FTEs) in the Canadian gastroenterology workforce from 2005 to 2026 (triangles), projected numbers of new clinical FTEs on a 1.3 annual rate (diamonds) and the representative curve indicating the estimated workforce size (FTEs plus projected number of new FTEs) (squares). B Projected reduction in clinical full-time equivalents (FTEs) in the Canadian gastroenterology workforce from 2005 to 2026 (triangles), projected numbers of new clinical FTEs on a 1.6 annual rate (diamonds) and the representative curve indicating the estimated workforce size (FTEs plus projected number of new FTEs) (squares)

quo or marginally increase the workforce (Figures $3 \mathrm{~A}$ and $3 \mathrm{~B}$ ). However, $88 \%$ of the current Canadian pediatric gastroenterology workforce indicated in the survey that the present number of Canadian pediatric gastroenterologists was inadequate to meet the current demands of the Canadian pediatric population.

\section{DISCUSSION}

The data obtained in the current workforce survey complement and expand on Canada-specific findings published in the two previous NASPGHAN surveys conducted between February 1996 and June 1996, and November 2003 and June 2004 (1,2). The initial NASPGHAN survey identified 48 Canadian pediatric gastroenterologists, with the number increasing to 60 on the subsequent survey. The present study identified 64 practicing Canadian pediatric gastroenterologists as of February 2005 and 67 as of May 2006.

In contrast to the predominance of male physicians in the American pediatric gastroenterology workforce $(73 \%$ of 650 physicians) (1), female physicians were well represented in the Canadian gastroenterology workforce. As of February 2005, Canadian female gastroenterologists accounted for 50\% (out of 64 gastroenterologists) of the workforce, representing a $27 \%$ increase from that observed in the NASPGHAN survey in 1996 (23\% of 48 gastroenterologists) (2). Moreover, in absolute numbers, a threefold increase in female pediatric gastroenterologists was observed (from 11 to 32 gastroenterologists). In contrast, American female gastroenterologists accounted for $27 \%$ of the 2003 to 2004 workforce, with only a modest increase observed from the survey in $1996(24 \%)(1,2)$. In addition, a larger proportion of the Canadian pediatric gastroenterology workforce was younger than 40 years of age compared with American pediatric gastroenterologists (39\% versus $18 \%$, respectively) (1). Female gastroenterologists were more likely to work part-time ( $12.5 \%$ versus $5 \%)$, likely due to their responsibility as the principal child care providers, the result being that these individuals had the pressure of child care in addition to their participation in the workforce.

The recent increase in concern regarding workforce adequacy in pediatrics and its subspecialties has been echoed in Canada, where there is ongoing concern that the current workforce of pediatric gastroenterologists across the country is inadequate to meet the needs and demands of the population served. The CAG pediatric committee survey confirmed the manpower shortage observed in the recent NASPGHAN survey (1), with $88 \%$ of Canadian respondents indicating that there were too few Canadian pediatric gastroenterologists. While the NASPGHAN surveys estimated a stable number of Canadian pediatric gastroenterologists per million children (zero to 17 years of age) between 1996 and 2004 (6.8 versus 5.9 to 6.7 ), the CAG survey estimated this number at 9.2 , which is similar to that observed for the USA in 2004 (8.1 to 9.2) $(1,2)$. The discrepant Canadian results obtained in the different surveys are believed to be due to the identification of a greater number of physicians by the present CAG study. The pediatric population differences between the NASPGHAN survey (population estimates for 2001) and the present study (population estimates for 2004) did not impact on the physician to child ratios $(1: 6,966,145$ versus $1: 6,967,853$ children zero to 17 years of age).

The total number of gastroenterologists fails to account for part-time staff, staff with largely administrative roles (eg, department heads), clinician scientists and medical educators. Thus, reconsidering the ratio of Canadian pediatric gastroenterologists per million children (zero to 17 years of age) utilizing physician clinical FTEs was associated with a 33\% decline in the ratio to just six pediatric gastroenterologists per million children. However, this number likely remains an overestimate, because administrative and educational responsibilities were not excluded when determining clinical FTEs unless an individual was considered to be a clinical educator or department head.

Additional confounding variables affecting workforce adequacy include an increasing tendency to decrease workload or alter job description with increasing age, changing referral practices of primary care physicians, and increasing requests of Canadian families for access to specialists. Finally, as demonstrated by data presented here regarding FTEs, the overall number of physicians does not accurately reflect the working capacity of the workforce.

There are few publications addressing adequacy of the pediatric subspecialty workforce (4-9). Recent publications have detailed the current workforce certified by the American Board of Pediatrics in pediatric endocrinology (10) and pediatric 
hematology-oncology (11). The cross-sectional data obtained listed 11 and 19 subspecialists, respectively, per 1,000,000 children younger than 18 years of age in the 50 states and the District of Columbia. However, the total manpower listed may have underestimated the actual working force in these disciplines, because these data did not include pediatricians working in these fields but who were not American Board of Pediatricscertified in the subspecialty. The NASPGHAN survey, listing between 8.1 and 9.2 sub-specialists per 1,000,000 children, represents the closest comparison to the Canadian pediatric gastroenterology data. It is true that the size of the Canadian pediatric population was estimated by Statistics Canada to have increased just marginally over the past 10 years, while the Canadian pediatric gastroenterology workforce increased by approximately 33\% (1996 to 2004). However, the crucial question that still remains to be answered is: what is the ideal physician to pediatric population ratio? The increasing proportion of female pediatric gastroenterologists in Canada and the observation that more female pediatric gastroenterologists work parttime than their male counterparts results in an availability of subspecialists that is far less than the total number would predict. Additionally, recent data have suggested that the incidence and prevalence of IBDs, conditions almost exclusively managed by gastroenterology subspecialists, continue to increase in Canada (12). The estimation that $0.5 \%$ of the Canadian population has IBD represents the highest rate published to date, and with many subjects presenting in childhood, it provides further support of the ongoing importance of maintaining an adequate gastroenterology workforce in upcoming decades.

Access to health care is further affected by variability in the distribution of subspecialists across the country. The larger urban centres, including Toronto, Montreal, Calgary, Edmonton and Vancouver, have relatively large numbers of pediatric gastroenterologists, each with varying degrees of nonclinical time protection. In contrast, the territories, Saskatchewan, Manitoba and the Maritime provinces are relatively sparsely manned. The net result is that patient care workloads vary markedly across the country.

The present survey demonstrated that smaller and midsized institutions are less able to protect physicians participating in nonclinical activities from clinical work overloads than larger institutions. It appears that individual physicians working in smaller centres were under increasing pressure to ensure that clinical responsibilities of the division were met at the expense of nonclinical activities. On the other hand, larger medical centres appeared more able to protect physicians and ensure preservation of job profiles, which was considered, by those surveyed, to be related to organizational structure, salary support and higher physician numbers.

Complementary data that would prove useful are clinic waiting times for pediatric gastroenterology patients across the country. There are currently no guidelines as to acceptable waiting times for different presenting pediatric gastroenterology symptoms, but such data are now available for adult gastroenterology patients in Canada (13-15). Such data relevant to children would provide additional evidence that would help to determine whether a larger pediatric gastroenterology workforce is required.

Utilization of the adult gastroenterology workforce to assume care for certain pediatric patients may help the current situation. However, a number of pediatrics-centred issues make this an improbable solution. A subspecialty workforce analysis (16), published in 2005, highlighted some of these issues. Typically, pediatric care is more time-consuming, with barriers to obtaining histories and physical examinations based on age, frequent need for reassurance and repeated explanations, and need for more sedation, including general anesthesia, compared with procedures performed in adults. Certain conditions encountered in pediatric practice, such as congenital malformations and inborn errors of metabolism, are not familiar to adult specialists. Additionally, remuneration for pediatric gastroenterologists is significantly less than for adult gastroenterologists, largely due to remuneration based on volume of services rendered, which, as indicated, is significantly lower in pediatrics (17). For these reasons, it is unlikely that the adult gastroenterology workforce will or should assume care of pediatric patients, except possibly in the case of the older adolescent patient.

The present study also serves to highlight ongoing concerns regarding secure funding to support fellowship training programs and inadequate numbers of Canadian trainees entering pediatric gastroenterology fellowship programs. Limited secure funding has been available to support Canadian fellows, and when support has been available, most programs require additional competitive funding for the third year of training. While Canadian trainees are considered first, the limitation of secure funding for Canadian fellows appears to have led to the inclusion of a high proportion of international trainees, who come with secure external funding into Canadian pediatric gastroenterology fellowship programs.

An alarming observation of the present study is that the projected number of Canadian pediatric gastroenterologists who will enter the workforce over the next 20 years $(2.0$ to 24 trainees per year or 1.3 to 1.6 clinical FTEs per year) will either just maintain the status quo or marginally increase the workforce. However, such calculations do not take into account potential clinical workload reductions with increasing age of workforce members due to alterations in job profiles, changing demographics of the workforce with an increasing proportion of female pediatric gastroenterologists and younger members with a greater interest in nonmedical activities. For example, the recent NASPGHAN survey (1) demonstrated that fewer Canadian pediatric gastroenterologists worked fulltime than that observed in the initial survey ( $84 \%$ versus $95 \%$, respectively), and the difference between men (95\%) and women $(71 \%)$ working full-time was significant $(\mathrm{P}=0.04)$. Moreover, $88 \%$ of the current Canadian pediatric gastroenterology workforce felt that the number of Canadian pediatric gastroenterologists was inadequate to meet current demands of the Canadian pediatric population.

An additional concerning trend has been a decline in the number of Canadian trainees entering and graduating from pediatric gastroenterology fellowship training programs. While the reasons for the decline remain to be determined, the lack of secure funding may be a contributory factor. Such concerns are not specific to pediatrics gastroenterology. It has been a reality that in recent years, fewer residents have been accepted into general pediatrics residency programs. A static or even increasing number of subspecialties are thus left with the task of attracting a smaller number of potential applicants. The CAG, recognizing this changing trend, instituted the CAG Scholars' Program, or Bright Lights program, which has been held annually since 2001 to raise the profile of gastroenterology among 
pediatric and medical residents (18). An effort must be made to secure adequate funding for potential trainees throughout the country to ensure that lack of funding support is not a limiting factor. Moreover, beyond the training period, there should be efforts made to address the wage discrepancy between adult and pediatric gastroenterologists to bring pediatric specialists' remuneration closer to that of their adult colleagues.

\section{CONCLUSIONS}

The findings of the present survey of Canadian pediatric gastroenterologists highlight the overall low number of available pediatric gastroenterology subspecialists across Canada. Additionally, an increasing percentage of workforce members are female, who are more likely to work part-time. The projected retirement rates, increasing demands on the workforce and, for some, an increased desire to partake in nonclinical activities, together with the limited number of new pediatric

\section{REFERENCES}

1. North American Society for Pediatric Gastroenterology, Hepatology and Nutrition. Pediatric Gastroenterology Workforce Survey, 2003-2004. J Pediatr Gastroenterol Nutr 2005;40:397-405.

2. Colletti RB, Winter HS, Sokol RJ, Suchy FJ, Klish WJ, Durie PR. A position paper of the North American Society for Pediatric Gastroenterology and Nutrition. Pediatric gastroenterology workforce survey and future supply and demand. J Pediatr Gastroenterol Nutr 1998;26:106-15.

3. Statistics Canada. <www.statcan.ca> (Version current at August 9, 2007)

4. Stockman JA III. Workforce Issues in General Pediatrics and the Pediatric Subspecialties. In: Pediatric Diplomates - A Newsletter from the American Board of Pediatrics. USA: The American Board of Pediatrics, 2004:1-3.

5. Shipman SA, Lurie JD, Goodman DC. The general pediatrician: projecting future workforce supply and requirements. Pediatrics 2004;113:435-42.

6. Althouse LA, Stockman JA III. Pediatric workforce: A look at general pediatrics data from the American Board of Pediatrics. J Pediatr 2006;148:166-9.

7. American Academy of Pediatrics Committee on Pediatric Workforce. Pediatrician workforce statement. Pediatrics 2005;116:263-9.

8. Mayer ML, Preisser JS. The changing composition of the pediatric medical subspecialty workforce. Pediatrics 2005;116:833-40.

9. Stoddard JJ, Cull WL, Jewett EA, Brotherton SE, Mulvey HJ, Alden ER. Providing pediatric subspecialty care: A workforce analysis. AAP Committee on Pediatric Workforce Subcommittee on Subspecialty Workforce. Pediatrics 2000;106:1325-33. gastroenterologists projected to enter the Canadian pediatric gastroenterology workforce, suggest that there will be an increasing shortage of pediatric gastroenterologists in the next decade.

While our adult gastroenterology colleagues may provide support in adolescent patients, the special needs of children limit adult involvement. Involvement of general pediatricians can be increased to deal with issues such as constipation and gastroesophageal reflux; however, the complexity of diseases and the procedural aspects of the subspecialty limit their involvement in many children.

ACKNOWLEDGEMENTS: The CAG Pediatric Committee expresses their appreciation to all those workforce members who provided the information that has been incorporated into the manuscript. The committee would also like to thank Dr D Butzner and Dr P Sherman for their valuable and insightful input.

10. Althouse LA, Stockman JA III. Pediatric Workforce: A look at pediatric endocrinology data from the American Board of Pediatrics. J Pediatr 2006;149:10-1.

11. Althouse LA, Stockman JA III. Pediatric Workforce: A look at pediatric hematology-oncology data from the American Board of Pediatrics. J Pediatr 2006;148:436-7.

12. Bernstein CN, Wajda A, Svenson LW, et al. The epidemiology of inflammatory bowel disease in Canada: A population-based study. Am J Gastroenterol 2006;101:1559-68. (Erratum in 2006;101:1945).

13. Leddin D. Canadian Association of Gastroenterology launches human resources planning initiatives. Can J Gastroenterol 2004;18:583-7.

14. Canadian Association of Gastroenterology. Human resource planning project: Wait times. <http://www.cag-acg.org/whatsnew/ hrplanningproject.htm) (Version current at August 14, 2007).

15. Paterson WG, Depew WT, Pare P, et al. Canadian consensus on medically acceptable wait times for digestive health care. Can J Gastroenterol 2006;20:411-23.

16. Jewett EA, Anderson MR, Gilchrist GS. The pediatric subspecialty workforce: Public policy and forces for change. Pediatrics 2005;116:1192-202.

17. Cejka Search. 2006 AMGA physician compensation survey. $<$ http://www.cejkasearch.com/compensation/amga_physician compensation_survey.htm> Version current at August 14, 2007.

18. Gregor J. Reflections on the third Annual CAG Scholars' Program. Can J Gastroenterol 2003;17(7):455. <http://www.pulsus.com/Gastro/ 17_07/Pdf/newe_ed.pdf> (Version current at August 14, 2007). 


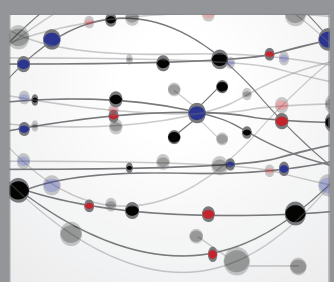

The Scientific World Journal
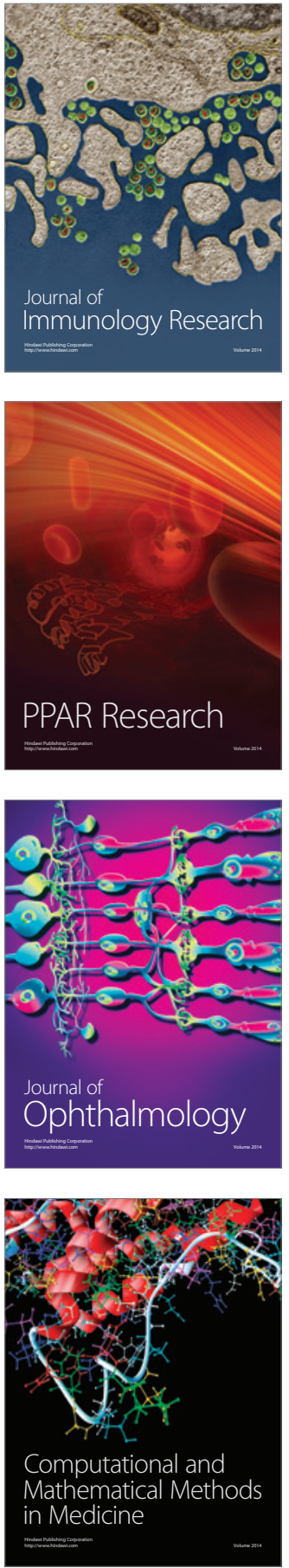

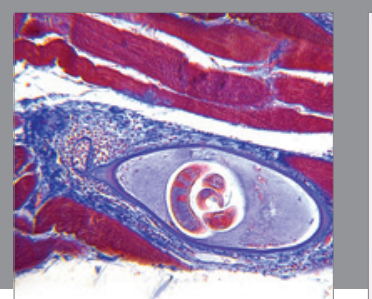

Gastroenterology Research and Practice

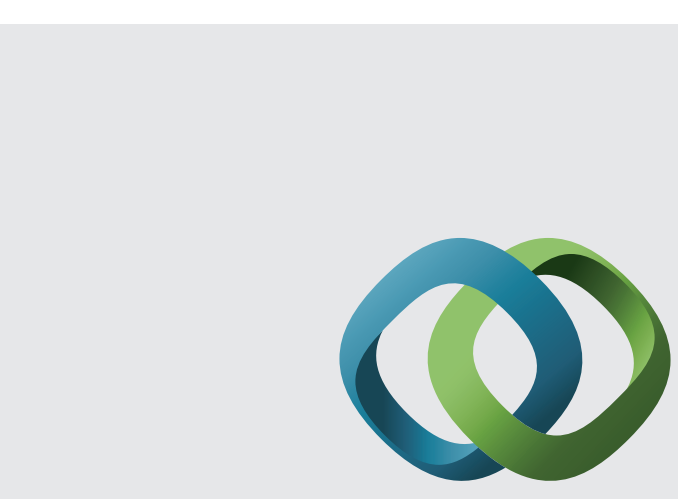

\section{Hindawi}

Submit your manuscripts at

http://www.hindawi.com
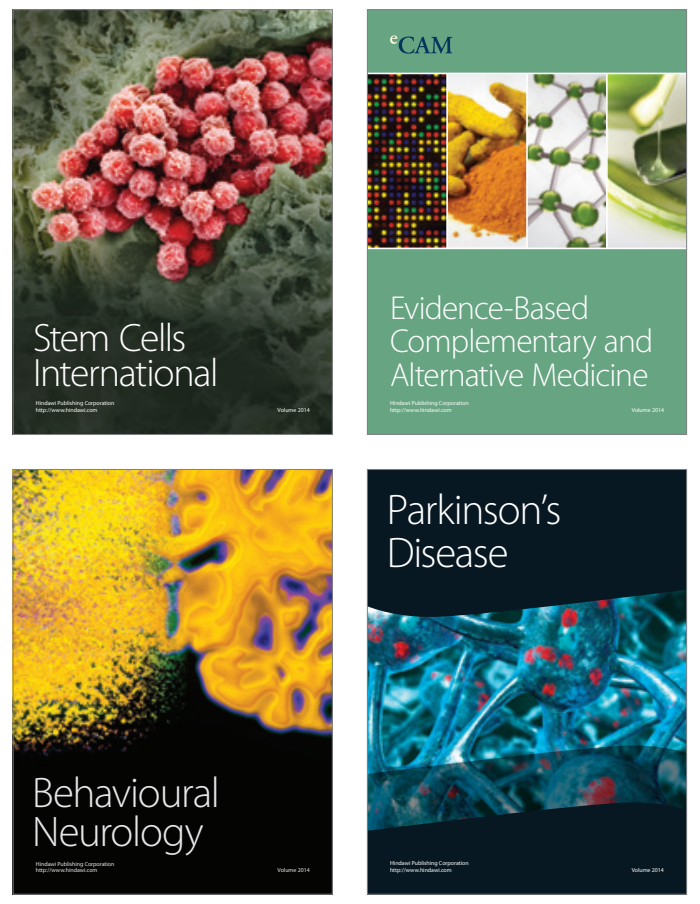
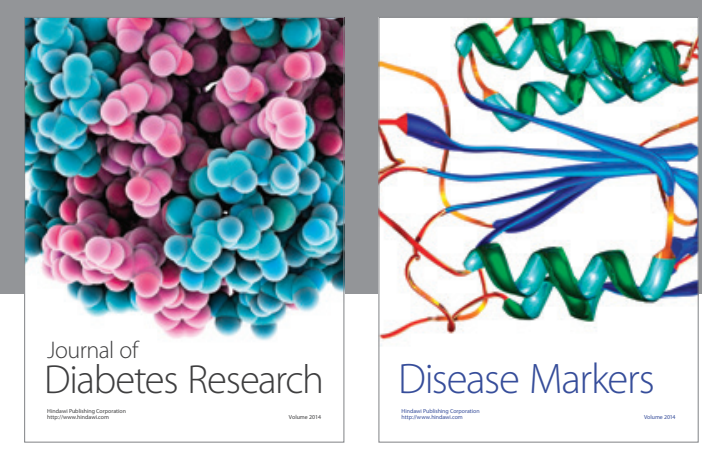

Disease Markers
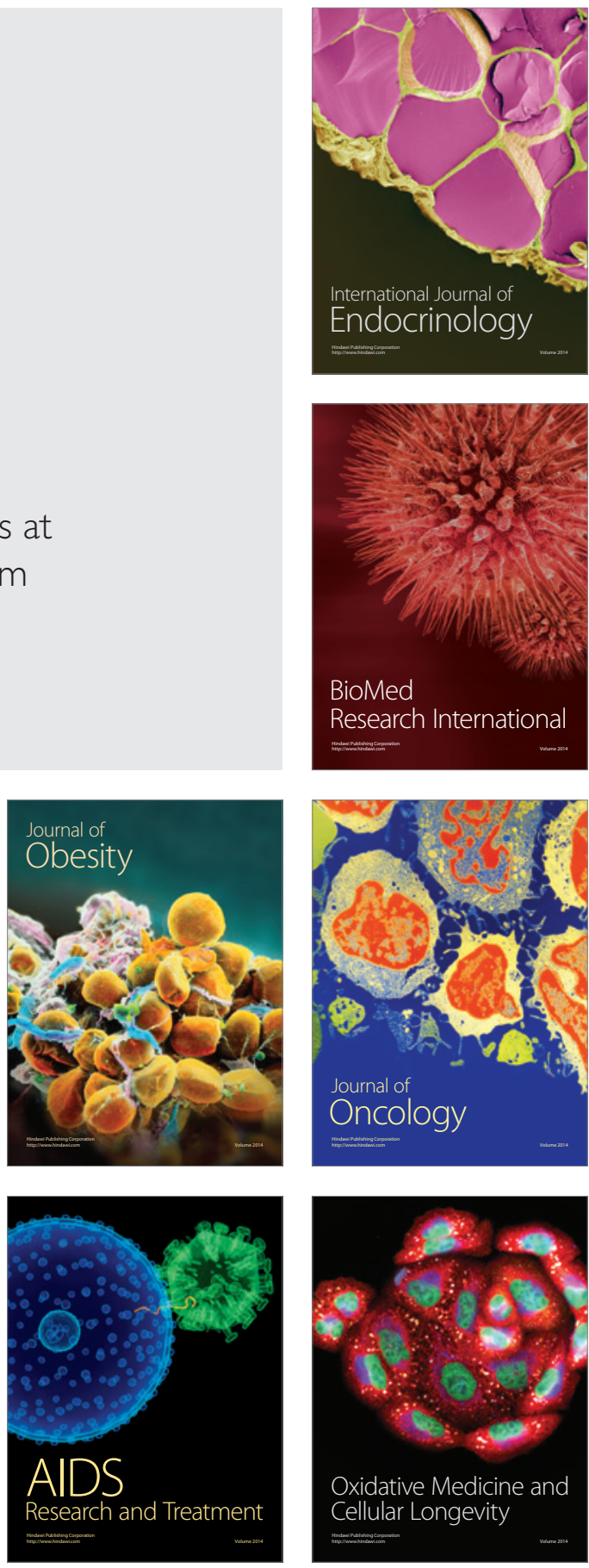